\title{
KAMPUS MERDEKA UNTUK MELAHIRKAN MANUSIA UNGGUL DALAM SEMANGAT GOTONG ROYONG
}

\author{
Ola Rongan Wilhelmus \\ STKIP Widya Yuwana \\ olarongan@yahoo.com
}

\begin{abstract}
Indonesia's human development index is still low among ASEAN countries. This losing quality of human resources results in decisions taken often not in favor of the interests of the nation. The low quality of human resources has resulted in one of the national development agendas as stipulated in the National Medium Term Development Plan IV (RPJMN-IV) currently putting strong pressure on improving human resources. The independent campus policy is designed to reinforce the position of tertiary institutions as a center for superior Indonesian human resources, and at the same time challenge tertiary institutions to continue of building a sustainable education system which is directly related to economic, social, and environmental aspects, as well as 21st century life and work skills demanded.
\end{abstract}

Keywords: Human resources, independent campus, tertiary institution, continuing education system.

\section{PENDAHULUAN}

Kementerian Pendidikan dan Kebudayaan terus berupaya menerapkan kebijakan baru pendidikan tinggi sebagai hasil kerja sama atau gotong royong antara perguruan tinggi dengan berbagai elemen masyarakat. Kebijakan ini memberi penekanan kuat bahwa tanggung jawab pendidikan tinggi tidak hanya menjadi tanggung jawab eksklusif institusi perguruan tinggi melainkan juga tanggung jawab masyarakat. Era baru pendidikan tinggi ini lahir dengan nama: “Merdeka Belajar: Kampus Merdeka”. Kebijakan kampus merdeka merupakan langkah awal upaya pemerintah meninggalkan praktek pendidikan yang terlalu dibebani persoalan administratif serta keterbatasan ruang gerak proses pendidikan dan pembelajaran itu sendiri.

Kebijakan pendidikan tinggi selama ini tidak memberi banyak kesempatan kepada mahasiswa untuk belajar di luar ruang kuliah dan kampus. Banyak kampus kurang antusias terhadap program pertukaran mahasiswa atau praktik kerja lapangan karena dipandang menghambat dan menunda waktu kelulusan. Kebijakan perguruan tinggi seperti ini dipandang kurang fleksibel, menghambat inovasi pembelajaran, dan kurang membuka ruang untuk kerjasama dan semangat gotong royong antara perguruan tinggi dengan dunia kerja dan masyarakat. 
Karena alasan ini maka kebijakan lama perlu diperbaharui melalui gerakan kampus merdeka yang memiliki 4 (empat) point utama yang akan menjadi salah satu bagian diskusi dari tulisan ini.

Gerakan kebijakan kampus merdeka memunculkan beberapa pertanyaan mendasar yang perlu dijawab yaitu: apa itu kebijakan kampus merdeka yang sesungguhnya? Apa dasar hukum kebijakan kampus mereka? Bagaimana manfaat dan tantangan kebijakan kampus merdeka untuk mahasiswa dan perguruan tinggi?. Berdasarkan pertanyaan tersebut, maka tulisan ini dibuat dengan tujuan: mendalami kebijakan kampus merdeka, mengidentifikasi payung hukum kebijakan kampus merdeka, serta menganalisis manfaat dan tantangan kebijakan kampus merdeka bagi perguruan tinggi dan mahasiswa.

Tulisan ini berturut-turut memberi uraian dan diskusi tentang hakekat kampus merdeka, posisi perguruan tinggi sebagai ujung tombak pencipta sumber daya manusia yang unggul, payung hukum kampus merdeka, serta manfaat dan tantangan kampus merdeka bagi perguruan tinggi dan mahasiswa ke depannya.

\section{PEMBAHASAN}

\subsection{Kampus Merdeka}

Merdeka Belajar: Kampus Merdeka merupakan kebijakan yang diluncurkan Menteri Pendidikan dan Kebudayan Nadiem Anwar Makarim pada tanggal 24 Januari 2020. Kebijakan ini tidak lain merupakan implementasi konsep tentang merdeka belajar sebagai manifestasi konkrit komitmen pemerintah mencetak pemimpin masa depan bangsa Indonesia yang memahami kebutuhan masyarakat dan dunia kerja. Kebijakan ini juga tidak lain merupakan realisasi visi dan misi pembangunan Presiden Joko Widodo terkait sumber daya manusia Indonesia yang unggul. Kata kunci yang perlu digenggam dari kebijakan kampus merdeka ialah inovasi, kreativitas, dukungan dan semangat gotong royong atau kerja sama antara pemerintah, perguruan tinggi, dunia kerja dan berbagai organisasi nirlaba untuk menghasilkan lulusan perguruan tinggi yang memiliki sumber daya manusia yang unggul atau berkualitas (Kemendikbud: 2020; Liput 6. 2020).

Melalui semangat gotong royong atau kerjasama ini, Kementerian Pendidikan dan Kebudayaan bermaksud menciptakan era baru pendidikan tinggi, yaitu jenjang S-1 sebagai hasil kerjasama atau gotong royong segenap elemen masyarakat Indonesia. Terkait aspek gotong royong ini, Nadiem Makarim di depan peserta Rapat Kordinasi Pendidikan Tinggi di Jakarta pada Januari 2020 mengatakan "bukan hanya perguruan tinggi yang bertanggung jawab atas pendidikan mahasiswa Indonesia tetapi seluruh masyarakat Indonesia”. Semangat gotong royong ini diperlukan dalam rangka mempersiapkan mahasiswa menjadi sarjana yang unggul, tangguh, relevan dengan kebutuhan zaman, dan siap menjadi 
pemimpin dengan semangat kebangsaan yang tinggi. Tekad menghasilkan sarjana tangguh dan berkualitas ini sejalan dengan Profil Pelajar Pancasila yaitu: berketuhanan, berakhlak mulia, menjunjung tinggi kebhinnekaan global, gotong royong, kreatif, bernalar kritis, dan mandiri (Pedoman Program Post Doctoral. 2020; Kemendikbud. 2020).

Kebijakan kampus merdeka juga membuka lebar peluang kerjasama dan semangat gotong royong antara perguruan tinggi dengan berbagai pihak luar untuk menciptakan program studi baru, memacu kemerdekaan berpikir, meningkatkan kompetensi dan profesionalisme kerja, fleksibilitas kurikulum, dan mengurangi beban admistrasi pendidikan. Kebijakan kampus merdeka merupakan langkah awal dari rangkaian upaya pemerintah membebaskan perguruan tinggi dari beban administrasi dan keterkurungan diri saat ini demi mempercepat gerak maju inovasi dan kreativitas perguruan tinggi (Kemendikbud: 2020; Liput 6. 2020). Nadiem (2020) mengatakan: "Ini tahap awal untuk membebaskan diri dari belenggu keterkurungan diri dan administratif pada perguruan tinggi agar perguruan tinggi lebih mudah bergerak maju”. Kebijakan ini mengisyaratkan adanya perubahan paradigma pendidikan tinggi yang lebih otonom dalam rangka menciptakan kultur pembelajaran secara lebih kreatif, inovatif, fleksibel, tidak mengekang dan lebih sesuai kebutuhan dunia kerja dan sekaligus mempersiapkan mahasiswa dalam dunia kerja sejak awal (Pedoman Program Post Doctoral. 2020; Kemendikbud. 2020).

Peraturan Menteri Pendidikan dan Kebudayaan (Permendikbud) Nomor 3 Tahun 2020 menjelaskan bahwa kebijakan kampus merdeka memiliki 4 (empat) paket kebijakan sebagai pondasinya yaitu otonomi perguruan tinggi mendirikan program studi baru; program reakreditasi Prodi dan PT secara otomatis; mempermudah proses PTN menjadi PTN-BH; dan memberi kebebasan kepada mahasiswa untuk melakukan kegiatan belajar di luar kampus (Kemendikbud. 2020; Pedoman Program Post Doctoral. 2020).

Sasaran utama kebijakan kampus merdeka ialah mengubah program S1 dengan cara mendorong mahasiswa supaya berani belajar di luar kampus dalam rangka mempersiapkan diri menghadapi tantangan masa depan yang begitu cepat berubah, penuh ketidakpastian dan siap "berenang di laut lepas”. Nadiem (2020) menjelaskan kebijakan kampus merdeka sangat erat kaitannya dengan penguatan karakter generasi muda. Implementasi kebijakan ini sangat bergantung pada kecepatan pimpinan perguruan tinggi meresponnya. Setiap kampus diharapkan dapat mempelajari secara menyeluruh dan mengimplementasikannya sesuai kebutuhan dunia kerja dan kondisi kampus masing-masing (Kemendikbud: 2020).

Kemendikbud menyadari bahwa sekitar 4.500 perguruan tinggi di Indonesia memiliki visi, misi, karakteristik serta tingkat kesiapan berbeda dalam merespon setiap kebijakan pemerintah terkait pendidikan tinggi. Menyadari hal ini 
maka penerapan kebijakan kampus merdeka tidak akan bersifat paksaan sebab kalau dipaksakan maka penerapannya bisa menjadi formalitas belaka. Diperlukan inovasi dan kreativitas pengelola perguruan tinggi untuk merespon dan mengimlementasi kebijakan kampus merdeka ini di setiap perguruan tingginya masing-masing (Kemendikbud: 2020).

\subsection{Perguruan Tinggi Pencetak SDM yang Unggul}

Data Human Developmen Report (2019) mengungkapkan bahwa indeks pembangunan manusia Indonesia masih rendah diantara negara Asean, yaitu menempati ranking ke-111 dengan rata-rata lama masa sekolah 8 tahun. Sementara itu, Singapura berada di rangking ke-9, Brunai ke-43, Malaysia ke-61, dan Thailand ke-77 dari 189 negara. SDM yang kurang bermutu ini mengakibatkan sering terjadi pengambilan kebijakan tidak berpihak pada kepentingan dan produk dalam negeri (Panduan Bimtek Lesson Study untuk Pengembangan Kompetisi Dosen LPTK, 2020).

Melihat rendahnya mutu SDM ini maka salah satu agenda Pembangunan Nasional yang dituangkan di dalam Rancangan Teknokratik: Rencana Pembangunan Jangka Menegah Nasional IV (RPJMN-IV) tahun 2020-2024 ialah meningkatkan sumber daya manusia yang berkualitas dan berdaya saing. Sumber daya manusia yang dimaksudkan oleh RPJMN - IV ialah sumber daya manusia yang sehat, cerdas, adaptif, inovatif dan berkarakter. Selain itu, pembangunan ke depan juga diarahkan untuk mendorong tumbuhnya IPTEK yang mampu membangun dan mengelola sumber daya ekonomi, tata kelola pemerintahan dan pengambilan keputusan yang berpihak pada kepentingan bangsa dan negara. Pemerintah juga menginginkan agar postur pembangunan perekonomian Indonesia bersifat inklusif, berbasis luas, dan berlandaskan keunggulan sumber daya manusia serta kemampuan ilmu pengetahuan dan teknologi. Demi mencapai hal ini, perguruan tinggi memiliki peran yang sangat penting dan strategis dalam menciptakan sumber daya manusia yang unggul melalui pelaksanaan tri dharma perguruan tinggi (Pedoman Program Word Class Professor. 2020).

Merespon tanggung jawab perguruan tinggi menciptakan sumber daya manusia yang unggul ini, maka kampus merdeka dirancang untuk mempertegas posisi perguruan tinggi sebagai ujung tombak pencetak sumber daya manusia yang unggul untuk menjawab kebutuhan industri, perusahan, dunia kerja dan negara. Melihat posisinya ini maka perguruan tinggi sedapat mungkin didorong untuk bergerak lebih cepat dan maju memperkuat bekal para sarjana di Indonesia sesuai kebutuhan dan perkembangan zaman. Perguruan tinggi didorong untuk lebih cepat berinovasi, beradaptasi dan berubah secara lincah sesuai kebutuhan dunia kerja dan perubahan zaman (Kemendikbud: 2020). 
Kebijakan kampus merdeka menempatkan kreativitas dan inovasi pembelajaran serta pengabdian kepada masyarakat sebagai prioritas dalam rangka pengembangan sumber daya manusia yang unggul sebagai tujuan utama dari pendidikan tinggi dalam era globalisasi dan perubahan yang begitu cepat. Kreativitas dan inovasi belajar dalam rangka menghasilkan sumber daya manusia yang unggul ini hanya bisa terjadi di dalam suatu iklim pembelajaran yang lebih bebas dan tidak terbelenggu. Inilah spirit dari konsep kampus merdeka. Spirit kampus merdeka terungkap antara lain melalui kebijakan mempermudah prosedur membuka program studi baru sesuai kebutuhan industri dan negara, tuntutan dunia kerja dan kebutuhan masyarakat (Kemendikbud: 2020).

Kebijakan kampus merdeka diharapkan bisa menumbuh-kembangkan kerjasama, semangat gotong royong dan kepedulian segenap sivitas akademika dan dunia industri, dunia usaha, serta organisasi nirlaba untuk membangun kualitas sumber daya manusia Indonesia yang unggul. Kampus merdeka diharapkan bisa menghasilkan lulusan sarjana S1 yang lebih berkualitas, mampu menghadapi tantangan dunia kerja, dan merupakan produk hasil kerjasama atau gotong royong seluruh elemen masyarakat. Solusi untuk menjawab tuntutan sekaligus tantangan lulusan sarjana S1 yang berkualitas ini ialah mendukung kolaborasi antara perguruan tinggi dengan berbagai pihak di luar kampus untuk menciptakan prodi-prodi baru. Untuk hal ini, sektor industri, perusahan, dunia kerja dan organisasi nirlaba diharapkan aktif terlibat bersama dalam proses pembuatan kurikulum, program magang, dan rekruitmen tenaga kerja dalam rangka menghasilkan sumber daya manusia yang unggul (Kemendikbud: 2020).

Mendikbud secara khusus menghimbau para pemangku kepentingan dan pengelola pendidikan tinggi untuk membangun sistem pendidikan yang lebih kolaboratif, adaptif dan inovatif. Perguruan tinggi diharapkan melakukan penyesuaian-penyesuaian secara cepat berkaitan dengan mekanisme manajemen perguruan tinggi saat ini yang berusaha memacu keterbukaan dan kerjasama dengan berbagai elemen masyarakat dalam rangka menghadapi berbagai perubahan yang sedang terjadi begitu cepat. Perubahan itu tidak hanya berlangsung secara linear atau satu arah, melainkan saling terkait antara satu aspek dengan aspek yang lain. Menghadapi perubahan ini, semangat gotong royong, sinergi, sinkronisasi, dan kolaborasi merupakan pilihan yang wajib dilakukan pengelola dan pemangku kepentingan perguruan tinggi. Interaksi yang erat antara perguruan tinggi dengan dunia kerja serta berbagai elemen lain dalam masyarakat akan membawa kemajuan dan pembangunan bangsa, serta mewarnai budaya dan peradaban bangsa secara langsung. Kerjasama otentik dan organik ini menguntungkan semua pihak terutama perguruan tinggi, mahasiswa, dan dunia kerja (Mohamad Nur Asikin, 2020) 


\subsection{Kebijakan Kampus Merdeka}

\subsubsection{Otonomi Mendirikan Program Studi}

Kebijakan pertama kampus merdeka ialah memberi otonomi bagi Perguruan Tinggi Negeri (PTN) dan Perguruan Tinggi Swasta (PTS) membuka program studi (Prodi) baru. Kebijakan pertama ini muncul karena selama ini hanya PTN Badan Hukum (PTN-BH) yang diberi kebebasan membuka prodi baru, sementara itu proses perizinan prodi baru untuk PTS dan PTN Badan Layanan Umum (PTN-BLU) memakan waktu lama. Kebijakan ini dibuat untuk mengantisipasi arus perubahan dan kebutuhan akan "link and match" dengan dunia kerja dan industri. Jadi melalui kebijakan ini, perguruan tinggi dituntut supaya lebih adaptatif dengan perkembangan dan kemajuan yang terjadi, kebutuhan lapangan kerja, dunia industri dan masyarakat (Hasil Diskusi Sosialisasi Kebijakan Merdeka Belajar: Kampus Merdeka, 2020; Kemendikbud: 2020; Liput 6. 2020).

Otonomi mendirikan program studi baru ini diberikan dengan syarat bila PTN dan PTS memiliki akreditas A dan B serta telah melakukan kerja sama dengan mitra industri, perusahan, organisasi nirlaba atau dengan universitas yang terdaftar dalam 100 universitas terbaik dunia. Dunia industri yang bisa berkolaborasi mendirikan program studi baru antara lain perusahaan multinasional yang masuk dalam daftar Fortune 500 (Royal Dutch Shell, Nestlé, Toyota, dll), perusahaan teknologi global bereputasi sangat baik (Google, Apple, Amazon, Intel, Cisco Systems, dll), Startup teknologi yang sudah terbukti mengumpulkan dana sebesar minimum USD \$50 juta (Tokopedia, Traveloka, Gojek, dll), organisasi multilateral dan nirlaba kelas dunia (PBB, Bank Dunia, ADB, USAID, Gates Foundation, dll), BUMN berskala besar di tingkat nasional (PLN, BRI, Pertamina, dll) serta BUMD berskala besar di setiap provinsi (MRT, Bank BJB, Trans Jakarta, dll). Kerjasama antara perguruan tinggi dengan dunia industri ini tertuang dalam kesepakatan membuat kurikulum bersama, menyediakan praktik kerja (magang), penyerapan lapangan kerja setelah lulus (Hasil Diskusi Sosialisasi Kebijakan Merdeka Belajar: Kampus Merdeka, 2020; Kemendikbud: 2020; Liput 6. 2020).

Jikalau perguruan tinggi dapat membuktikan adanya kerja sama yang riil antara kedua belah pihak, maka program studi baru tersebut akan mendapat akreditasi C secara otomatis dari BAN-PT tanpa perlu mendapat persetujuan Kemendikbud. Akreditasi akan berlaku sampai dengan program studi baru ini mengajukan reakreditasi. Pembukaan program studi baru bagi perguruan tinggi yang memiliki akreditasi A dan B berlaku untuk semua jenjang (S1, S2, S3, profesi dan vokasi) pendidikan. Kemendikbud bekerjasama dengan perguruan tinggi dan mitra program studi untuk melakukan pengawasan, penyusunan kurikulum, praktik kerja, magang, serta penempatan kerja bagi para mahasiswa 
(Hasil Diskusi Kemendikbud dengan Peserta Sosialisasi Kebijakan Merdeka Belajar: Kampus Merdeka, 2020).

Kebijakan otonomi mendirikan program studi ini merupakan suatu tantangan yang sangat besar bagi para dosen, sebab para dosen dituntut memiliki kompetensi dan kemampuan lebih berkaitan dengan dunia internasional. Dosen dituntut memiliki kompetensi dan kemampuan membangun jejaring internasional serta memperkuat jejaring yang sudah ada terutama jejaring yang melibatkan perusahaan/industri berskala internasional. Kemampuan membangun jejaring sangat diperlukan agar pada masa mendatang jembatan antara dunia akademik dan dunia kerja semakin kokoh serta dapat menjawab kebutuhan para stake holder, dan menghasilkan lulusan perguruan tinggi yang memiliki kompetensi dan keterampilan bersaing di tingkat internasional (Pedoman Program SAMEScheme for Academic Mobility and Exchange. 2020).

Dosen sebagai seorang pendidik profesional dan ilmuwan dituntut terus mengembangkan bidang kajian keilmuannya dan terus mengupayakan inovasiinovasi yang dapat memberi pengaruh pada peningkatan layanan pendidikan dan mahasiswa sekaligus pada kesejahteraan masyarakat (UU Nomor 14 Thun 2005 tentang Guru dan Dosen). Jadi dosen dituntut untuk terus melakukan pengembangan profesioalisme secara berkelanjutan (continous professional development) melalui riset, menulis buku dan buku ajar, melakukan publikasi ilmiah, serta pengabdian kepada masyarakat (Pedoman Program Post Doctoral. 2020).

\subsubsection{Program Reakreditasi}

Kebijakan kedua kampus merdeka ialah memberlakukan program reakreditasi secara otomatis untuk semua jenjang pendidikan, dan bersifat sukarela bagi PT dan Prodi yang sudah siap naik peringkat. Akreditasi yang sudah ditetapkan Badan Akreditasi Nasional (BAN-PT) tetap berlaku selama 5 tahun namun akan diperbaharui secara otomatis. Kebijakan ini dikeluarkan dengan alasan karena selama ini semua PT dan Prodi wajib melakukan proses reakreditasi setiap 5 tahun, tetapi proses reakreditasi ini memakan waktu sampai dengan 170 hari untuk PT dan 150 hari bagi Prodi. Proses reakreditasi juga mengakibatkan dosen dan pengelola perguruan tinggi mendapat banyak tambahan beban administrasi (Hasil Diskusi Sosialisasi Kebijakan Merdeka Belajar: Kampus Merdeka, 2020; Kemendikbud: 2020; Liput 6. 2020).

Melihat permasalahan ini, maka Mendikbud mengambil kebijakan baru tentang akreditasi berdasarkan amanat Undang-undang No. 12 tahun 2012 tentang kewajiban akreditasi dan perpanjangan akreditasi bagi perguruan tinggi dan program studi demi menjamin dan mengontrol mutu perguruan tinggi. Akreditasi yang sudah ditetapkan BAN-PT tetap berlaku selama 5 tahun tetapi 
akan diperbaharui secara otomatis tanpa harus mengisi lagi borang akreditasi. Perguruan tinggi yang terakreditasi $\mathrm{B}$ atau $\mathrm{C}$ dapat mengajukan kenaikan akreditasi kapan saja secara sukarela. Pengajuan reakreditasi dibatasi paling cepat 2 tahun setelah mendapatkan akreditasi terakhir kali. Peninjauan kembali akreditasi akan dilakukan BAN-PT jika ada indikasi penurunan mutu PT atau Prodi melalui pengaduan masyarakat dan penurunan jumlah pendaftar dan lulusan dari PT dan Prodi secara drastis dalam 5 tahun berturut-turut. Evaluasi terkait mutu ini dipantau juga melalui laporan PD Dikti dan tracer study (Hasil Diskusi Sosialisasi Kebijakan Merdeka Belajar: Kampus Merdeka, 2020; Kemendikbud: 2020; Liput 6. 2020).

\subsubsection{Menjadi PTN Badan Hukum}

Kebijakan yang ketiga terkait dengan kebebasan bagi Perguruan Tinggi Negeri Badan Layanan Umum (PTN-BLU) untuk menjadi PTN Badan Hukum (PTN-BH). Kebijakan ini muncul karena selama ini terdapat aturan yang mewajibkan PTN-BLU harus mendapat akreditasi A sebelum menjadi PTN-BH, dan mayoritas (60 \%) program studi PTN-BLU harus terakreditasi A.Disamping itu, PTN-BLU selama ini dilihat kurang memiliki fleksibilitas finansial dan kurikulum bila dibandingkan dengan PTN-BH. Melihat permasalahan ini maka, Mendikbud mempermudah persyaratan bagi PTN-BLU untuk menjadi PTN-BH kalau merasa diri sudah siap tanpa harus memenuhi kewajiwan terakreditasi A dan mayoritas program studi terakreditasi A. (Kemendikbud: 2020; Liput 6. 2020).

Kemendikbudmempermudah persyaratan bagi PTN-BLU untuk menjadi PTN-BH agar PTN bisa bergerak lebih lincah seperti PTS. Jadiwalaupun didanai pemerintah, PTN-BH mendapatkan berbagai hak seperti PTS.Keunggulan lain yang didapatkan oleh PTN-BH ialah lebih leluasa bermitra dengan sektor industri, pengusaha, organisasi nirlaba dan bebas melakukan proyek komersial. Dari segi pengaturan keuangan, PTN-BH memiliki model pengaturan keuangan lebih otonom dan bisa melakukan perubahan secara cepat.Dengan mendapatkan status PTN-BHini diharapkan PTN dapat mengembangkan kegiatan akademik dan nonakademik lebih cepat, inovatif dan kreatif demi menghasilkan lulusan yang tangguh, memiliki sumberdaya manusia yang unggul, relevan dengan perubahan dan kebutuhan dunia kerja, dan mampu bersaing di tingkat internasional (Kemendikbud: 2020; Liput 6. 2020).

Dalam kaitan dengan persaingan pada tingkat internasional ini, Rancangan Teknokrat RPJMN 2020-2024 menargetkan publikasi ilmiah perguruan tinggi di Indonesia pada tahun 2017 sebanyak 16.147 hendaknya bisameningkat mencapai 36.500 pada thaun 2024. Demikian pulajumlah hak paten yang terdaftar di Indonesia pada tahun 2017 sebanyak 9.352, diantaranya hanya 2.271 (24\%) 
merupakan penemuan peneliti Indonesia bisa lebih ditingkatkan lagi pada tahun 2024. Pemerintah juga menargetkan ada 1 (satu) perguruan tinggi yaitu Universitas Indonesia masuk ke dalam Top 100 dunia dalam World University Rank (WUR), 2 (dua)perguruan tinggi yaitu Istitute Teknologi Bandung dan Universitas Gadjah Mada masuk dalam Top 300 WUR, dan 3 (tiga) perguruan tinggi yaitu Institut Pertanian Bogor, Universitas Airlangga, dan Universitas Padjadjaran masuk dalam Top 500 WUR (Pedoman Program Word Class Professor. 2020).

\subsubsection{Mengambil Mata Kuliah di Luar Prodi}

Kebijakan keempat kampus merdeka ialah memberikan hak kepada mahasiswa untuk belajar di luar kampus dan mengubah definisi tentang Satuan Kredit Semester (SKS). Kebijakan ini muncul karena selama ini mahasiswa dinilai tidak memiliki banyak fleksibilitas untuk mengambil kelas di luar kampus sendiri. Bobot SKS untuk kegiatan pembelajaran di luar kampus juga sangat kecil. Hal ini dilihat sebagai perlakuan tidak adil bagi mahasiswa yang sudah mengorbankan banyak waktu, tenaga dan dana untuk kegiatan di luar kampus. Banyak kampus bahkan menilai pertukaran mahasiswa dan praktik kerjadi luar kampus misalnya dapat menunda kelulusan, karena itu perguruan tinggi kurang mendorong mahasiswanya untuk kegiatan belajar di luar kampus (Kemendikbud. 2020; Hasil Diskusi Kemendikbud dengan Peserta Sosialisasi Kebijakan Merdeka Belajar: Kampus Merdeka, 2020).

Merespon permasalahan ini, Kemendikbud mewajibkan perguruan tinggi memberikan hak penuh kepada mahasiswa untuk secara sukarela belajar atau mengambil SKS di luar kampus sebanyak 2 semester atau setara dengan 40 SKS. Mahasiswa juga diperbolehkan mengambil SKS di prodi yang berbeda di PT yang sama sebanyak 1 semester atau setara dengan 20 SKS. Jadi SKS yang wajib diambil di prodi asal sebanyak 5 semester dari total semester yang wajib dijalankan. Berbicara tentang kegiatan di luar kampus, Nadiem memberi contoh pada dirinya sendiri. Dia mengaku sebagai lulusan Hubungan Internasional, tetapi pekerjaan yang digeluti lebih condong di bidang teknologi. Artinya apapun yang dipelajar dan dikerjakan selama kuliah sering kali hanya merupakan starting point. Karena itu mahasiswa perlu diberi kemerdekaan untuk melakukan berbagai macam kegiatan di luar kampus. (Hasil Diskusi Kemendikbud dengan Peserta Sosialisasi Kebijakan Merdeka Belajar: Kampus Merdeka, 2020).

Kebijakan belajar di luar kampus dapat mendorong mahasiswa untuk memilih jurusan studi yang lebih mutakhir dan sesuai dengan kebutuhan pengetahuan, keterampilan kerja dan pengembangan kemampuannya. Mahasiswa juga akan memperoleh materi dan proses pembelajaran yang lebih berkualitas karena berkurangnya beban administrasi dosen. Kebijakan ini tidak mengandung 
unsur pemaksaan bagi mahasiswa. Kalau mahasiswa ingin $100 \%$ belajar dalam prodinya sendiri, maka hal itu juga menjadi kebebasan mahasiswa yang harus dihargai (Hasil Diskusi Kemendikbud dengan Peserta Sosialisasi Kebijakan Merdeka Belajar: Kampus Merdeka, 2020).

Kebijakan memberi kebebasan kepada mahasiswa untuk belajar diluar kampus ini diikuti dengan perubahan definisi terhadap SKS. Setiap SKS diartikan sebagai “jam kegiatan”, bukan "jam belajar”. Jam kegiatan diartikan sebagai belajar di kampus dan di luar kampus. Setiap jenis kegiatan yang dipilih mahasiswa untuk dilaksanakan harus dibimbing seorang dosen yang ditentukan peruruan tinggi. Daftar kegiatan di luar kampus dalam 3 semester dapat dipilih dari program yang ditentukan pemerintah dan program yang disetujui rektor (Power point Presentasi Kemendikbud. 2020)

Alasan melakukan redefinisi terhadap SKS bersumber pada Permenristekdikti No. 44 Tahun 2015 yang mengartikan SKS sebagai takaran waktu kegiatan belajar berdasarkan proses pembelajaran serta pengakuan atas keberhasilan mahasiswa mengikuti kegiatan kurikuler. Selama ini, SKS lebih diartikan sebagai pembelajaran tatap muka di dalam ruang kuliah, padahal proses pembelajaran tidak terbatas pada kegiatan dalam ruang kuliah saja. Berdasarkan alasan legal ini, maka ditetapkan kebijakan baru yang memberi hak kepada mahasiswa secara sukarela melakukan kegiatan belajar di luar kampus dan dapat diperhitungkan sebagai SKS. Proses penghitungan SKS diberi kebebasan sepenuhnya kepada setiap perguruan tinggi (Hasil Diskusi Kemendikbud dengan Peserta Sosialisasi Kebijakan Merdeka Belajar: Kampus Merdeka, 2020).

Jenis kegiatan di luar kampus yang diusulkan Kemendikbud antara lain magang/praktek kerja, proyek desa, mengajar di sekolah, pertukaran mahasiswa, penelitian/riset, kegiatan kemahasiswaan, studi proyek independen, dan proyek kemanusiaan. Kegiatan magang dapat dilakukan di sebuah perusahan, yayasan nirlaba, organisasi multilateral, institusi pemerintah. Sementara itu proyek desa ialah proyek sosial untuk membantu masyarakat di pedesaan untuk membangun ekonomi rakyat, infrastruktur, dan lain-lain. Proyek ini dapat dilakukan bersama dengan aparatur desa (kepala desa), BUMDes, Koperasi, dan lain-lain (Power point Presentasi Kemendikbud. 2020)

Kegiatan mengajar di sekolah meliputi sekolah dasar, menengah, maupun menengah atas di kota maupun di desa tepencil. Pertukaran mahasiswa ialah kegiatan mengambil kuliah pada Prodi atau PT lain baik negeri maupun swasta. Kegiatan penelitian mencakup riset akademik baik sains maupun sosial humaniora. Kegiatan wirausaha mencakup pengembangan kewirausahaan secara mandiri yang dibuktikan dengan proposal kegiatan kewirausahaan dan bukti transaksi konsumen. Studi/proyek independen ialah kegiatan dimana mahasiswa diberi kesempatan untuk mengembangkan sebuah proyek berdasarkan topik sosial 
khusus dan dapat dikerjakan bersama mahasiswa lain. Proyek kemanusiaan ialah kegiatan sosial untuk sebuah yayasan atau organisasi kemanusiaan yang disetujui perguruan tinggi. Berbagai kegiatan di luar kampus ini bisa di implementasi dengan baik jikalau perguruan tinggi terbuka untuk kolaborasi dan interaksi dengan sesama penyelenggara pendidikan (pemerintah dan perguruan tinggi lain) maupun dengan pihak ketiga yaitu dunia usaha, dunia industri, organisasi nonprofit, dll dalam rangka memperluas konten pembelajaran (Power Point Presentasi Kemendikbud. 2020; Hasil Diskusi Kemendikbud dengan Peserta Sosialisasi Kebijakan Merdeka Belajar: Kampus Merdeka, 2020).

Kebijakan ini merupakan tantangan yang sangat besar bagi para dosen sebagai sumber daya manusia perguruan tinggi yang memiliki peran sangat sentral dan strategis dalam seluruh aktivitas di perguruan tinggi (Bdk. UU Nomor 20 Tahun 2003 tentang Sistem Pendidikan Nasional; UU Nomor 14 Tahun 2005 tentang Guru dan Dosen; Permen Nomor 42 Tahun 2007 tentang sertifikasi). Dosen tertantang untuk terus meningkatkan kualitasnya sebab kualitas dosen akan sangat menentukan tinggi rendahnya kualitas suatu perguruan tinggi, dan pada gilirannya menentukan pula tinggi-rendahnya kualitas generasi bangsa di masa yang akan datang (Pedoman Program SAME- Scheme for Academic Mobility and Exchange. 2020).

\section{4. $\quad$ Payung Hukum Merdeka Belajar Kampus Merdeka}

Kebijakan kampus merdeka memiliki landasan hukum berupa Peraturan Menteri Pendidikan atau Permendikbud Nomor 3 Tahun 2020 tetang Standar Nasional Pendidikan Tinggi; Permendikbud Nomor 4 Tahun 2020 tentang PTNBH; Permendikbud Nomor 5 tentang Akreditas Program Studi dan Perguruan Tinggi; Permendikbud Nomor 6 Tahun 2020 tentang Penerimaan Mahasiswa Baru Program Sarjana Perguruan Tinggi Negeri (PTN); Permendikbud Nomor 7 tentang Pendirian Perguruan Tinggi.

\subsubsection{Permendikbud Nomor 3 Tahun 2020}

Permendikbud Nomor 3 Tahun 2020 berkaitan dengan Standar Nasional Pendidikan Tinggi ini disusun dengan tujuan melaksanakan ketentuan Pasal 52 ayat (3) Undang-Undang Nomor 12 Tahun 2012 tentang Pendidikan Tinggi. Sebagaimana isi Pasal 52 ayat (3) UU Nomor 12 tahun 2012, Permendikbud ini menguraikan beberapa hal penting terkait arti pendidikan tinggi; standar nasional pendidikan tinggi; standar pengajaran, penelitian dan pengabdian kepada masyarakat.

Pendidikan tinggi diartikan sebagai jenjang pendidikan setelah pendidikan menengah. Pendidikan tinggi ini mencakup Program Diploma, Program Sarjana, Program Magister, Program Doktor, Program Profesi, dan Program Spesialis yang 
diselenggarakan perguruan tinggi berdasarkan kebudayaan bangsa Indonesia. Standar Nasional Pendidikan Tinggi adalah satuan standar yang meliputi Standar Nasional Pendidikan ditambah dengan Standar Penelitian dan Pengabdian kepada Masyarakat.

Standar Nasional Pendidikan Tinggi ditetapkan untuk dilaksanakan dengan tujuan menjamin tercapainya tujuan pendidikan tinggi yaitu mencerdaskan kehidupan bangsa, memajukan ilmu pengetahuan dan teknologi dengan menerapkan nilai humaniora, pembudayaan dan pemberdayaan bangsa Indonesia secara berkelanjutan; menjamin program studi, penelitian, dan pengabdian kepada masyarakat mencapai mutu sesuai dengan kriteria yang ditetapkan dalam Standar Nasional Pendidikan Tinggi; dan mendorong agar perguruan tinggi mencapai mutu pembelajaran, penelitian, dan pengabdian kepada masyarakat melampaui kriteria yang ditetapkan dalam Standar Nasional Pendidikan Tinggi.

Standar Nasional Pendidikan Tinggi terdiri atas standar kompetensi lulusan, standar isi pembelajaran, standar proses pembelajaran, standar penilaian pendidikan pembelajaran, standar Dosen dan Tenaga Kependidikan, standar sarana dan prasarana pembelajaran, standar pengelolaan, dan standar pembiayaan pembelajaran. Standar Nasional Pendidikan ini menjadi acuan dalam menyusun, menyelenggarakan, dan mengevaluasi kurikulum pendidikan.

\subsubsection{Permendikbud Nomor 4 Tahun 2020}

Permendikbud Nomor 4 Tahun 2020 pada intinya memberi uraian tentang alasan mengubah status PTN-BLU dan Satker menjadi PTN-BH. Dijelaskan bahwa perubahan PTN menjadi PTN-BH dilakukan atas beberapa pertimbangan yaitu: (1) dalam rangka meningkatkan kualitas pendidikan tinggi, maka dipandang perlu memberikan kemudahan dan fleksibilitas bagi PTN untuk menjadi PTN-BH; dan (2) Permendikti Nomor 88 Tahun 2014 tentang PTN menjadi PTN-BH dinilai belum memberikan kemudahan dan fleksibilitas bagi PTN-BLU untuk menjadi PTN-BH. Sebagai contoh, Permendikti Nomor 88 Tahun 2014 telah menetapkan beberapa persyaratan bagi PTN untuk menjadi PTN-BH yaitu adanya tingkat dan derajat kemampuan PTN untuk menyelenggarakan Tridharma Perguruan Tinggi yang bermutu.

Penyelenggaraan Tridharma Perguruan Tinggi yang bermutu menurut Permendikti Nomor 88 tahun 2014 antara lain, PTN memiliki akreditasi A; memiliki paling sedikit $60 \%$ program studi dengan peringkat akreditasi A; adanya relevansi antara visi, misi, dan tujuan dengan Standar Pendidikan Tinggi yang terdiri atas Standar Nasional Pendidikan Tinggi dan Standar Pendidikan Tinggi yang ditetapkan Perguruan Tinggi sendiri; hasil publikasi internasional dan hak kekayaan intelektual, dan lain-lain. Kriteria-kriteria ini dipandang terlalu berat dan menghambat proses perubahan status PTN-BLU menjadi PTN-BH. Kemendikbud 
melalui Permendikbud Nomor 4 Tahun 2020 memberi kebebasan kepada PTNBLU merubah status menjadi PTN-BH jikalau sudah sungguh-sungguh siap dengan tujuan supaya PTN dapat mengembangkan setiap kegiatan akademik dan non-akademik secara lebih cepat, inovatif dan kreatif.

\subsubsection{Permendikbud Nomor 5 Tahun 2020}

Permendikbud Nomor 5 Tahun 2020 diterbitkan untuk mengatur akreditasi PT dan Prodi sekaligus untuk melaksanakan ketentuan Pasal 55 ayat (8) UU No. 12 Tahun 2012 tentang Pendidikan Tinggi. Pasal 55 UU No. 12 Tahun 2012 mengartikan Perguruan Tinggi sebagai satuan pendidikan yang menyelenggarakan pendidikan tinggi, dan program studi merupakan kesatuan kegiatan pendidikan dan pembelajaran yang memiliki kurikulum dan metode pembelajaran tertentu dalam satu jenis pendidikan akademik, pendidikan profesi, dan pendidikan vokasi.

Akreditasi program studi diartikan sebagai kegiatan penilaian untuk menentukan kelayakan program studi, sedangkan akreditasi perguruan tinggi merupakan kegiatan penilaian untuk menentukan kelayakan perguruan tinggi. Akreditasi program studi diselenggarakan oleh Lembaga Akreditasi Mandiri (LAM). Lembaga ini dibentuk oleh pemerintah atau masyarakat untuk melakukan akreditasi program studi secara mandiri. Akreditasi perguruan tinggi dilakukam oleh BAN-PT yang dibentuk oleh pemerintah untuk melakukan dan mengembangkan akreditasi perguruan tinggi secara mandiri.

Akreditasi merupakan sistem penjaminan mutu eksternal sebagai bagian dari sistem penjaminan mutu pendidikan tinggi. Akreditasi program studi dan perguruan tinggi bertujuan: menentukan kelayakan program studi dan perguruan tinggi berdasarkan kriteria yang mengacu pada Standar Nasional Pendidikan Tinggi dan menjamin mutu program studi dan perguruan tinggi secara eksternal baik bidang akademik maupun non akademik untuk melindungi kepentingan mahasiswa dan masyarakat. Jangka waktu berlakunya akreditasi untuk program studi atau perguruan tinggi dibawah BAN-PT ialah 5 (lima) tahun.

Permendikbud Nomor 5 Tahun 2020 ini mengatakan bahwa bila masa berlaku 5 tahun akreditasi itu berakhir, maka BAN-PT akan memperpanjang kembali jangka waktu akreditasi selama 5 (lima) tahun secara otomatis tanpa melalui permohonan perpanjangan akreditasi. Perpanjangan akreditasi ayat (2) dapat dilakukan berdasarkan evaluasi oleh Kementerian dan/atau laporan masyarakat tentang dugaan pelanggaraan peraturan perundang-undangan dan/atau penurunan mutu dalam penyelenggaraan pendidikan tinggi. Peringkat akreditasi Prodi dan PT terdiri atas: Baik (C); Baik Sekali (B); dan Unggul (A).

\subsubsection{Permendikbud Nomor 6 Tahun 2020}


Permendikbud Nomor 6 Tahun 2020 tentang Penerimaan Mahasiswa Baru program Sarjana pada PTN. Permendikbud ini diterbitkan untuk melaksanakan ketentuan Pasal 73 ayat (7) Undang-Undang Nomor 12 Tahun 2012 tentang Pendidikan Tinggi, terutama Perguruan Tinggi Negeri. PTN adalah perguruan tinggi yang didirikan dan/atau diselenggarakan pemerintah.

Sejalan dengan ketentuan Pasal 73 ayat (7) Undang-undang Nomor 12 Tahun 2020, Permendikbud No. 6 Tahun 2020 mengatakan bahwa prinsip dan jalur penerimaan mahasiswa baru program Sarjana pada PTN diselenggarakan atas prinsip-prinsip adil, akuntabel, fleksibel, efisien, dan transparan. Adil berarti tidak membedakan agama, suku, ras, jenis kelamin, umur, kedudukan sosial, kondisi fisik, dan tingkat kemampuan ekonomi calon mahasiswa dengan tetap memperhatikan potensi dan prestasi akademik calon mahasiswa dan kekhususan program studi di PTN bersangkutan. Akuntabel berarti dilaksanakan sesuai dengan prosedur dan kriteria yang jelas. Fleksibel artinya diselenggarakan beberapa kali dan setiap calon mahasiswa dapat menempuh paling banyak dua kali Ujian Tulis Berbasis Komputer (UTBK). Efisien artinya penyelenggaraan tes masuk PTN menggunakan teknologi informasi dan komunikasi, pelibatan sumber daya manusia, dan fleksibilitas waktu. Transparan artinya pelaksanaan penerimaan mahasiswa baru PTN dilakukan secara terbuka dan hasil pelaksanaan diakses secara mudah.

Jalur Penerimaan Mahasiswa Baru program Sarjana pada PTN dilakukan melalui Seleksi Nasional Masuk PTN (SNMPTN). Jalur seleksi ini dilakukan berdasarkan hasil penelusuran prestasi akademik, non-akademik, dan/atau portofolio calon mahasiswa. Seleksi Bersama Masuk PTN (SBMPTN) ini dilakukan berdasarkan hasil UTBK dan dapat ditambah dengan kriteria lain sesuai dengan talenta khusus yang ditetapkan PTN bersangkutan. Seleksi lainnya dilakukan berdasarkan seleksi dan tata cara yang ditetapkan masing-masing pemimpin perguruan tinggi.

\subsubsection{Permendikbud Nomor 7 Tahun 2020}

Permendikbud Nomor 7 Tahun 2020 diterbitkan untuk mengatur hal pendirian, perubahan, pembubaran PTN, dan pendirian, perubahan, pencabutan izin Perguruan Tinggi Swasta. Permendikbud Nomor 7 Tahun 2020 ini dibuat untuk melaksanakan ketentuan Pasal 31 ayat (4), Pasal 34 ayat (2), dan Pasal 92 ayat (3) Undang-Undang Nomor 12 Tahun 2012 tentang Pendidikan Tinggi; Pasal 7 ayat (1 dan 2), Pasal 12 Peraturan Pemerintah Nomor 4 Tahun 2014 tentang Penyelenggaraan dan Pengelolaan Pendidikan dan Perguruan Tinggi.

Pendirian PTN adalah pembentukan Universitas, Institut, Sekolah Tinggi, Politeknik, Akademi, dan Akademi Komunitas oleh Pemerintah. Perguruan Tinggi Swasta (PTS) adalah perguruan tinggi yang didirikan dan/atau 
diselenggarakan oleh masyarakat. Pendirian Perguruan Tinggi Swasta adalah pembentukan Universitas, Institut, Sekolah Tinggi, Politeknik, Akademi, dan Akademi Komunitas oleh Badan Penyelenggara berbadan hukum yang berprinsip nirlaba.

\subsection{Peluang dan Tantangan Kebijakan Kampus Merdeka}

Banyak pelaku pendidikan di perguruan tinggi optimistis terhadap kebijakan kampus merdeka karena dinilai memberikan ruang kebebasan lebih besar kepada mahasiswa untuk melakukan berbagai kegiatan di luar program studi hingga tiga semester. Kebijakan seperti ini diyakini dapat menciptakan ruang lebih terbuka dan fleksibilitas bagi mahasiswa untuk bersentuhan dengan pengalaman kerja dan belajar di lapangan melalui proyek desa, magang, praktik industri dan lain-lain. Hal ini akan membuat mahasiswa jauh lebih siap menghadapi kerja dan tantangan masa depannya. Rektor Institut Pertanian Bogor (IPB) Arif Satria mengatakan optimistis terhadap kebijakan Kampus Merdeka karena kebijakan ini memberikan kebebasan kepada mahasiswa untuk melakukan beragam kegiatan di luar program studinya sendiri selama tiga semester. Program ini memberi fleksibilitas bagi mahasiswa bersentuhan dengan dunia kerja dan persoalan hidup konkrit di lapangan. Hal ini akan membuat mahasiswa jauh lebih siap menghadapi dunia kerja dan masa depannya sendiri (Kemendikbud: 2020; Liput 6. 2020; Power Point Presentasi Kemendikbud. 2020).

Meskipun demikian sejumlah pengamat pendidikan menilai bahwa kebijakan kampus merdeka dapat mengurangi mutu riset dan inovasi. Merespon pandangan ini, Mendikbud menegaskan bahwa riset yang diperlukan saat ini adalah riset yang transformatif, kolaboratif, multi-disiplin keilmuan, bersentuhan dengan realitas dan memberikan solusi atas persoalan yang ada. Kebijakan kampus merdeka justru akan menjadi inspirasi bagi riset. Selain itu, melalui kebijakan ini, dosen dapat membantu mahasiswa S2 dan S3 melakukan riset, mahasiswa dan dosen bisa berkontribusi dalam pembangunan desa, dan dapat menciptakan suatu kurikulum pembelajaran sendiri berdasarkan pengalaman belajar dan riset lapangan (Kemendikbud. 2020; Liput 6. 2020; Power Point Presentasi Kemendikbud. 2020).

Tantangan yang diakui cukup besar terkait kampus merdeka ialah upaya menjalin kemitraan serta bagaimana membuat kesepakatan yang tepat dan cocok dalam jangka panjang dengan pihak mitra kerja. Kesepakatan ini merupakan tugas yang harus segera diselesaikan pihak perguruan tinggi. Kampus merdeka membutuhkan dukungan dan kerja sama dengan berbagai pihak mulai dari sivitas akademika, kementerian hingga dunia kerja dan industri. Perguruan tinggi harus bekerja keras membangun kerja sama ini agar "link and match" antara perguruan tinggi dengan dunia industri, dunia kerja dan organisasi non-profit semakin baik 
dan berkembang. Merespon tantangan ini, banyak pelaku pendidikan di perguruan tinggi optimis bahwa pihaknya dapat menjalankan kerja sama dengan mitra kerja seperti dunia industri dan lain-lain (Kemendikbud. 2020).

Tantangan lain ialah perlindungan terhadap mahasiswa magang. Hal ini akan menjadi perhatian Kemendikbud dan perguruan tinggi agar mahasiswa magang mendapatkan hak dan kewajiban sesuai dengan peraturan yang berlaku. Dengan durasi magang lebih lama, mahasiswa mendapat peluang untuk memperoleh kompetensi lebih baik dalam dunia industri, perusahan dan dunia kerja. Sebaliknya dunia industri juga mendapatkan manfaat lebih besar karena mahasiswa magang akan mendapatkan lebih banyak waktu untuk memahami suatu pekerjaan. Mahasiswa magang dengan kompetisi baik, tentu akan menjadi kandidat pertama ketika perusahaan tersebut melakukan rekruitmen pegawai (Kemendikbud. 2020; Power Point Presentasi Kemendikbud. 2020).

Pada akhirnya, perguruan tinggi dan pemerintah di tantang untuk terus membangun sistem pendidikan berkelanjutan dengan terus memperhatikan aspek ekonomi, sosial, dan lingkungan, serta keterampilan abad 21 yang meliputi 4 Cs: Critical thinking, Creative, Collaborative, dan Communication Skills. Perguruan tinggi dan pemerintah tertantang untuk terus melakukan percepatan pemerataan dalam peningkatan mutu SDM dalam konteks kondisi geografi dan demografi Indonesia sehingga Indonesia semakin kompetitif di dunia global (Panduan Bimtek Lesson Study untuk Pengembangan Kompetisi Dosen LPTK, 2020).

Merespon tantangan ini, pemerintah Indonesia melalui Kemendikbud sedang melakukan berbagai upaya, termasuk memperbaiki kurikulum pendidikan tinggi dan membangun iklim baru dunia pendidikan tinggi melalui kebijakan “Merdeka Belajar: Kampus Merdeka” yang diwujudkan dalam berbagai program pemberian pengalaman belajar di kampus lain dan di dunia industri (Panduan Bimtek Lesson Study untuk Pengembangan Kompetisi Dosen LPTK, 2020).

\section{PENUTUP}

Kampus merdeka adalah langkah awal upaya pemerintah membebaskan perguruan tinggi dari keterkurungan diri dan beban administrasi demi mempercepat gerak maju inovasi dan kreativitas perguruan tinggi. Kata kunci yang perlu digenggam dari kebijakan kampus merdeka ialah inovasi, kreativitas, dukungan dan kerja sama antara pemerintah, perguruan tinggi, dunia kerja dan berbagai organisasi nirlaba untuk menghasilkan lulusan perguruan tinggi yang memiliki sumberdaya manusia yang unggul atau berkualitas

Kampus merdeka dirancang tidak hanya untuk memperkuat peranan perguruan tinggi sebagai ujung tombak pencetak sumber daya manusia yang unggul untuk menjawab kebutuhan negara dan tuntutan dunia kerja, tetapi juga menantang para dosen untuk terus meningkatkan kualitasnya sebab kualitas dosen 
akan sangat menentukan tinggi rendahnya kualitas suatu perguruan tinggi dan masa depan kualitas generasi bangsa.

\section{DAFTAR PUSTAKA}

CNN Indonesia. 2020. Nadiem Buat Lima Payung Hukum untuk Kebijakan Kampus Merdeka. https://www.cnnindonesia.com/nasional/20200210100210-20473163/nadiem-buat-lima-payung-hukum-untuk-kebijakan-kampusmerdeka.

Kemendikbud. 2020. Kebijakan Kampus Merdeka: Mahasiswa Dapat Ambil Pelajaran di Luar Prodi. ps://www.kemdikbud.go.id/main/blog/2020/01/kebijakan-kampusmerdeka-mahasiswa-dapat-ambil-pembelajaran-di-luar-prodi.

Kemendikbud. 2020. Kebijakan Kampus Merdeka Beri Otonomi Perguruan Tinggi Buka Prodi Baru. https://www.kemendikbud.go.id/main blog/2020/01/kebijakan-kampus-merdeka-beri-otonomi-perguruan-tinggibuka-prodi-baru.

Kemendikbud. 2020. Mendikbud Luncurkan Empat Kebijakan Merdeka Belajar Kampus Merdeka. https://www.kemdikbud.go.id/main/blog/2020/01/mendikbud-luncurkanempat-kebijakan-merdeka-belajar-kampus-merdeka.

Kemendikbud. 2020. Hasil Diskusi Kemendikbud dengan Peserta Sosialisasi Kebijakan Merdeka Belajar: Kampus Merdeka, 2020).

Liputan 6. 2020. Kebijakan Kampus Merdeka Ala Mendikbud Nadiem Anwar

Makarim. https://www.liputan6.com/news/read/4165124/ini-4-kebijakankampus-merdeka-ala-mendikbud-nadiem-makarim.

Panduan Bimtek Lesson Study untuk Pengembangan Kompetisi Dosen LPTK, 2020. Dirjen Pendidikan Tinggi Kemendikbud.

Pedoman Program Post Doctoral. 2020. Dirjen Pendidikan Tinggi Kemendikbud.

Pedoman Program Word Class Professor. 2020. Dirjen Pendidikan Tinggi Kemendikbud.

Pedoman Program SAME-Scheme for Academic Mobility and Exchange. 2020. Dirjen Pendidikan Tinggi Kemendikbud.

Peraturan Menteri Pendidikan dan Kebudayaan Republik Indonesia Nomor 3 Tahun 2020 tentang Standar Pendidikan dan Kebudayaan Republik Indonesia tahun 2020.

Peraturan Menteri Pendidikan dan Kebudayaan Republik Indonesia Nomor 4 Tahun 2020 tentang perubahan atas Peraturan Menteri Pendidikan dan Kebudayaan Nomor 88 Tahun 2014 tentang Perubahan Perguruan Tinggi Negeri menjadi Perguruan Tinggi Negeri Badan Hukum. 
Peraturan Menteri Pendidikan dan Kebudayaan Republik Indonesia Nomor 5 tahun 2020 tentang akreditasi program studi dan perguruan tinggi.

Peraturan Menteri Pendidikan dan Kebudayaan Nomor 6 tahun 2020 tentang Penerimaan Mahasiswa Baru program Sarjana pada Perguruan Tinggi Negeri.

Peraturan Menteri Pendidikan dan Kebudayaan Nomor 7 tahun 2020 tentang pendirian, perubahan, pencabutan izin Perguruan Tinggi Swasta. 